\title{
The Human Body and the Plant World: Mutual Relations of the Codes (1)
}

\author{
Valeria B. Kolosova \\ Institute for Linguistics \\ St. Petersburg, Russia
}

\begin{abstract}
The article analyses reflections of the anthropomorphic code in the plant code of traditional Slavonic culture. There exist: 1) the language level (using body parts names in phytonyms); 2) the folklore level (aetiological stories about the genesis of plants from the human body); and 3) the level of ritual (using body parts to influence the plants, rules and taboos concerning planting). Plants are also used to influence the human body (usually in folk medicine) on the basis of similarity of their parts.
\end{abstract}

A common principle stands behind this "anthropomorphization" on all three levels-it semioticizes the objective features of a plant. In the "ideal" case, there is a phytonym using a body part in the naming of a plant, an aetiological story about the plant, and rules for using it. Anthropomorphization structures and regulates the sum of knowledge about the plant world. However, this is not just a question of the mutual relations between the two codes, but a part of the system, where sustainability is maintained in at least two ways: the "vertical" (the possibility of expressing the same sense in a text, a word, and a ritual), and the "horizontal" (the possibility of expressing the same sense in different codes). That demonstrates the systematic character of the mythological world model.

Never plant a birch or a fir tree near your house, peasants in East Slav areas would advise, because it will drive the women from the house. Both were seen as female trees. In Serbia the red of peonies came, it was believed, from blood shed at the crucial battle of Kosovo Field in 1389. Both these examples reveal links between the plant and the human worlds. In this article I seek to demonstrate the relationship between the two codes in traditional Slavic culture that relate to the human body and plants, and more specifically, reflections of the human body code in the plant code. The data is amenable to structuring in a variety of ways. It would be feasible, for example, to concentrate on levels, first that of 
lexis, then folklore, and lastly ritual, or alternatively select a given feature as a unit of description. I have, however, chosen to take individual body parts as building blocks. In this way I can avoid repetition, as the correlation of a plant with a part of the body on the basis of a feature results (in the most developed instances) in a phytonym (plant name), in folklore texts, recommendations on how to use the plant in folk medicine and in a ritual. In my discussion below I give the common name in English where the given plant has one, as well as the Latin name.

\section{Body Parts}

\section{The Head}

Phytonyms with the component golova (head) are generally used for plants that possess spherical parts (such as flower clusters or fruits): in Vladimir province in Russia sobach'ia golova [dog's head] is the term for meadow knapweed, Centaurea jacea L., while in Kursk Centaurea scabiosa L., greater knapweed, is called krasnogolovki [red heads], and in Siberia adamova golova [Adam's head]. In Ukraine adamova golova [Adam's head] refers instead to meadow eryngo, Eryngium campestre L., [Annenkov 1876: 90-91; Bulashev 1909: 349].

The conventional reaction to the effects of hemlock, Conium maculatum L., is reflected in the names given to it: Rus. boligolov, golovolom, Ukr. bolyholov, Srb. glavobolno zelje, boleglav, boliglav [the headache herb] [Avgustinovich 1853: 26; Machek 1954: 76; Čajkanović 1985: 151], while water hemlock, Cicuta virosa L., is known similarly as boligolov, golovolom [Annenkov 1876: 98]. Hellebore, Helleborus niger, has a similar reputation, reflected in the Serbian glavobolka, or glavobolcica [headache herb], and the belief that you should not bring it into the house for fear of getting a headache [Čajkanović 1985: 75]. In riddles too it is supposed that plants can have a head, for example, one Russian riddle about the thistle declares: "Стоить колихаеться, красною головою величаеться, лежачи бодаеться" [it sways as it stands, haughty with its red head, stabs you when it's lying down] [Chubinskii 1877: (I, 2) 305].

There are numerous occasions when a plant name exists alongside a legend, explaining the name; these can be understood as variants of the same text, but with differing degrees of elaboration. Thus, in Smolensk province speedwell, Veronica latifolia L., was known as Ivan bezgolovyi [Ivan the headless], because the flower cluster is higher than the stem, 
which looks like it has been bitten off. An etiological legend explains this feature in the following way: “девка отрубила некоему Ивану голову, а тот пошел жаловаться Боородице, неся свою голову на копье. Богородица превратила Ивана в цветок вероники" [A girl cut off a certain Ivan's head, so he went to the Virgin to complain, carrying his head on a spear. The Virgin turned him into a speedwell plant] [Demich 1899: 1169].

As we have seen already, phytonyms with the component golova [head] include both plants with spherical parts and those believed to cause a headache. But the same is true for plants used to cure a headache. Sometimes the two groups overlap: “высока, тоненька, две-три головки беленьки у нее, адамова голова от больной головы помогает, вон, гляди, по угору шарики голубые, колючие" [tall and slender, two or three white heads it has, adamova golova helps with a headache; there, look, on the slope, blue prickly round heads] (2) [Rodionova 2002: 38]. Or in Ukrainian of bolyholov [hemlock] it is said "при головной боли мочат настоем этой травы" [when the head aches, moisten [the forehead?] with an infusion of this herb] [Markovich 1891: 425].

It was further supposed that the name of a feast day may influence the formation and growth of vegetables. For example, in Ukraine cabbages planted on 25 May/7 June, the feast of Saint John, which was known as Ivan Holovatyi [Ivan the Big Head Day], are believed to have large heads. At the level of ritual actions, women would touch their heads with both hands, so that the cabbage would grow large and firm [Moroz 2000: 134].

\section{The Hair}

Rock-cress, Arabis arenosa, is called in Polish panieńczyne włosy [maiden's hair], because after blooming its pericarps (the outer cover of the seed) turn wavy like a girl's hair [Usacheva 2000: 263]. There are similar names in Ukraine for various different plants: bogorodishna kosa [the plait of the Theotokos] for Astragalus Cicer L.; bogomaterina kosa [the plait of the Mother of God] for creeping St John's wort, Hypericum humifusum L.; boroda chortova [devil's beard] for white dogbane, Vincetoxicum officinale L. [Bulashev 1909: 349].

East Slavic dialectal phytonyms of the kind voloshka, voloshki are etymologically connected with hair (Rus. volos) and generally denote plants that have different parts covered with hair-like fibers, such as haresfoot clover, Trifolium arvense L. (a hairy calyx) devil's bit 
scabious, Scabiosa arvensis (a hairy stalk and leaves), the corn cockle, Lychnis githago Scop. (a grey and hairy herb), or marsh cudweed, Gnaphalium uliginosum L. (covered with matted whitish hairs) [Zalesova, Petrovskaia 1899-1901: (2-4), 472, 513, 540, 949].

The Face

The bright spot, the "eye", in the centre of the dark flower of the violet, Viola tricolor L., was commonly reflected in its name. Examples include the following: in Russia in Volodga they are known as vesiolye glazki [jolly eyes] but aniutiny glazki [Anna's eyes] in Moscow and Kursk provinces, while in Serbian they are dikino oko [wild eye], and in Bulgarian dialect divi ocheta [wild eyes] [Annenkov 1876: 382; Čajkanović 1985: 84]. In one Ukrainian legend a rusalka (a mythological creature in the form of a beautiful girl) turns a handsome youth into a cornflower; the flower is the same bright blue as his eyes [Markevich 1860: 86-87]. The dialectal names for eyebright, Euphrasia officinale L., glaznitsa, glaznaia trava, ochanka, ochnaia trava in Russian, ochanka in Ukrainian, and očanica in Serbian, reflect the fact that it was used to treat eye problems. This usage was probably inspired by the fact that in the corolla of its flower there is a spot resembling an eye [Annenkov 1876: 141]. The predominant use of eyebright for eye problems is also mentioned by Machek [1954: 215].

The dialectal names for coral root, Dentaria bulbifera L., are all linked with teeth; hence Rus. bab'i zuby, zubnitsa, Pol. babie zęby, zubowa bylina, Srb. zubatka, Lusatian zubica, all meaning woman's teeth, or tooth herb. According to Ukrainian legend, garlic grew out of the teeth of a witch, which is why it is a sin to eat it [Bulashev 1909: 379], while in Eastern Poles'e on the borders of Russia, Ukraine, and Belarus, the root of an orchid resembling a tooth was believed to help ease toothache [SA 3: 596].

\section{The Hands and Arms}

Common names for the primrose, Primula veris L., come from the shape of its floscules (flower clusters): Ukr. bozha ruchka, bozhi ruchki [God's hand(s)] [Annenkov 1876: 272]. In Serbian, knot-grass, Illecebrum, is called nokatac [the fingernail herb], because its tough grooved leaves are shaped like narrow finger nails [Machek 1954: 76].

In Poland a legend was recorded about the plant known as dalonka, meaning palm of the hand, to the effect that it grew from a mitten lost by the Virgin [Usacheva 2000: 281]. Herbs with leaves in a form of a paw 
or hand were often used to heal a rash between the fingers, as in the Russian name mezhperstitsa, mezheparshchitsa [lit. between-the-fingersplant] for lady's-mantle, Alchemilla vulgaris L.. In Smolensk province it was said that if there is swelling between the fingers, cover it with the dried leaves of the lady's-mantle; and it may be noted that in the local dialect mezheparshchitsa also means a rash on the hands, an itch or a scab. Fresh or dry leaves were also used to treat itching feet [Dobrovol'skii 1914: 407].

The forked and double roots of orchids led to different superstitions in various local traditions. According to Bulgarian and Belarusian beliefs, the root of the orchid looks like the palm of a hand with five fingers, something reflected in its names: Bulg. rbchitsa [hand]; Bel. dalonka [palm]. The root was used by the Belarusians as a contraceptive [SA 2: 596], while among the South Slavs a woman in childbirth would drink an infusion of the herb ruka Fatimy [Fatima's hand] or bogoroditsyna ruchka [the hand of the Mother of God], because this herb, shaped like an open hand, will help her body open up in the same way [SA 3: 596]. (3)

In the province of Kazan' in Russia, the fragrant orchid, Gymnadenia conopsea R. Br., bore the names liub-trava or liubovny ruchki [love herb, love hands]. When making a love potion a specimen with "hands" (i.e. tubers) pointing towards each other was used; if the "hands" pointed away from each other, the plant would be used for the opposite effect, namely to repel love [Krylov 1882: 35-36]. By contrast, there are fewer beliefs relating to the arms as opposed to the hands, but in the Russian province of Kaluga, common storks-bill, Erodium cicutarium L., was drunk as a medicine for convulsions, because the petioles (where the leaf stalk joins the main stem) are drawn together like elbows, as if in convulsions [Annenkov 1876: 136].

\section{The Torso}

It is perhaps unsurprising that Adam's rib comes to be associated with a plant in Ukrainian, specifically adamove rebro, Thysellinum palustre L., but more surprising when the ribs of other biblical personages are involved. Thus, also in Ukraine, we find a kind of valerian, Valeriana dubia Bung., being called chortove rebro [devil's rib] [Bulashev 1909: 349], while in Perm' province greater knapweed, Centaurea scabiosa L. was known as khristosovy riobra [Christ's ribs] and was used for back pain [Annenkov 1876: 91]. A Russian legend 
recounts the story that the potato grew from a sorcerer's grave, out of his rib [Usacheva 2000: 273].

The common name for snakeweed, Polygonum bistorta L., which is widely used to treat stomach disorders, reflects its use in folk medicine. It is called zaviaznyi koren' [tying root] in Moscow and Archangel provinces; in Viatka province it is zhivotnyi koren' [belly root] or zholunichnyi koren' [stomach root], and in Serbian zheludniak [stomach root] [Annenkov 1876: 264]. At the same time the Ukrainian term zaviaznyk [tying herb] refers to common tormentil, Tormentilla erecta L., with the plant being used to treat diarrhea or vaginal bleeding [Avgustinovich 1853: 73-74]. Here similar names are given to different plants because of the similarity or identity of their medicinal use.

Children who were suffering from sukhotka, a wasting disease, were bathed in a solution of a plant known as tolstushka [literally fatty plant], Ledum acre L. The medicinal use was clearly based on its morphological features; “листья растения толстые, сочные. Отсюда и дети должны "потолстеть" [the leaves of the plant are fat and juicy. Hence the children were expected to "get fat" as well] [Markovich 1891: 426]

\section{The Genitalia}

The lexis relating to genitalia may also be reflected in plant names, as, for example, in Russia, where rebiach'i miudushki [children's testicles] is the term for Satyrium L. Meantime in Serbian popova muda [priest's testicles] denotes the spindle tree, Euonymus europaeus L., while Bulgarian dialect has mominski sram, mŭzhko sramniche, and Serbian sramak [all meaning penis] for the wild carrot [Annenkov 1876: 142, 316; SA 3: 301].

A whole series of plants is included in a group of riddle texts with erotic connotations. These plants may be perceived as either male or female and include grapes, and maize, the cucumber which is paired with the fig, haricot, and pumpkin. Some plant names are ambiguous and can refer to either gender. These include pepper, cabbage, and the walnut [Sikimić 1996].

Common names of plants with parts in the shape of genitalia reflected that resemblance and were used in love and fertility magic. Of these the chief was the orchid family, in Russian iatryshnik, the word supposedly deriving from iatro [belly, testicles, balls], because of its knob-shaped roots [Annenkov 1876: 232]. It has different names in various dialects, but its use is virtually identical everywhere. For example, Orchis latifolia L., the broad-leaved Fen orchid “по народным 
представлениям, является растением, возбуждающим любовь и способствующим увеличению половой силы... у гуцулов с помощью ятрышника лечили от мужской слабости" [in popular conception is thought capable of evoking love and increasing sexual potency ... the Hutsuls in south western Ukraine used it as a treatment for impotence] [Potanin 1899: 233], while elsewhere women tried to guess the sex of their unborn child from the shape of its root: elongated for a boy, and round for a girl [Kedrina 1912: 102, 108]. Afanas'ev quotes another variant of this type of divination: a two-pronged root meant a girl and a three-pronged root - a boy [Afanas'ev 1994: (3), 227].

In Ukraine, Orchis palustris Jacq., was called krasnye sultanchiki [red plumes]; “им приписывают свойство возбуждения половых органов" [their roots were believed to stimulate the sexual organs] [Avgustinovich 1853: 50]. Another name for this plant is liubka (derived from the root liub-, "love"): "Некоторые особенности в устройстве корня этого растения дали повод употреблять его как средство заставить полюбить друг друга. Корень бывает двоякий: оканчивающийся отростками наподобие пальцев (мужской пол) и просто в виде сердца, без отростков (женский). Нужно накопать таких корней, высушить, настоять на водке и дать выпить “парубкови й дивчыни” поровну, приговаривая: “Любылыся въ лисныхъ лугахъ ціи цвиточкы, и вы, диточкы, въ своихъ хатахъ любиться, якъ ціи цвиточкы въ лугах"” [certain features of its root prompted its use as a means of making people fall in love. The root is double: with branches looking like fingers (male) and a simple heart shape without protuberances (female). You had to dig up these roots, dry them, make an infusion in vodka with them and give the drink to a young man and woman, saying: "These flowers loved each other in the forest meadows; now you, children, in your homes love each other like these flowers in the fields"] [Khatemkin 1900: 8-9]. Similar properties were ascribed to the members of the orchid family in Czech folk culture [Machek 1954: 299].

In Kaluga province “если где-нибудь жена с мужем живут не в ладу, мужа поят настоем этого корня" [if a husband and wife are not getting on, an extract of orchid root will be given to the husband]; here the black root represented the husband, and the white root the wife [Kedrina 1912: 107-08].(4) Using Orchis maculata L. in love magic is also mentioned by Annenkov: “крестьянки ворожеи дают корень носить с собою, дабы другие любили, и особенно замужним женщинам при несогласии с мужьями" [fortune-tellers give the root to 
peasant women to carry around with them so that they will be loved, and especially to married women who are not getting on with their husbands] [Annenkov 1876: 233].

It is very likely that the belief in the Archangel region about the herb known locally as kukusha [cuckoo plant] also relates to a plant from the orchidaceae family: “корень на двое: один муж, а другой жена. Когда муж жену не любит, дай пить жёночке, а жена мужа не любит, дай пить мужичку, станет любить женочка" [the root is divided in two, this representing a husband and his wife. If a husband doesn't love his wife, then the wife should be given this (herb) to drink, and if a wife doesn't love her husband, it (the herb) should given to him to drink, and then his wife will love him] [Kharitonov 1848: 15].

Lastly, erotic motifs are also found in magic relating to garden vegetables; if the cucumbers are not growing well and producing large numbers of sterile flowers, in the Homel' area in Belarus a man with no trousers had to wave a scythe over the cucumber beds [SA 3: 498]. In the Homel' area wives asked their husbands to lie down in the furrow to ensure a good crop of large cucumbers [SA 3: 498].

\section{The Pelvis}

Prevalent among all the Slavs was the practice, used when vegetables were being planted, of women sitting naked on the vegetable beds so that the vegetables would turn out as big as their pelvis.

\section{The Skin}

In Vologda province the greater celandine, Chelidonium majus L., was known as chistotel (lit. the clean body herb) because it was used to get rid of warts [Ivanitskii 1890: 148]. In Kazan' province it was used in the bathhouse to scrub a rash [Krylov 1882: 69]. It was also known as borodavnik, borodavochnik [wart herb]. In Kursk province children who had a skin disease were bathed in its extract [Annenkov 1876: 94], while in the Perm' region it was the yellow (or woodland) whitlow grass, Draba nemorosa L., known locally as chistotel detskii [children's clean body herb], that was taken internally for skin diseases in children [Annenkov 1876: 94, 398].

\section{Bodily fluids}

In phytonyms bodily fluids are generally represented by tears and blood. 


\section{Tears}

The similarity of a plant to one body part or another gives the plant its characteristic semantics and typical connotations; for example, the resemblance of peas to teardrops caused them to be strongly associated with future misfortune or disaster. According to an etiological legend, the pea grew from Adam's tears as he wept while ploughing the land for the first time after expulsion from the Garden of Eden [Bulashev 1909: 378], while according to a Belarusian legend, the mountain ash grew from Eve's bloody tears after the Fall [Nikiforovskii 1897: 129].

\section{Blood}

In many Slavic areas great burnet, Sanguisorba officinalis L. (Rus. krovokhliobka, krovososka [blood-sucker], Srb. krvara, Czech krvavec, krvavnik [blood herb]) is so called because of its blood-red flowers. The many local plant names for perforate St. John's wort, Hypericum perforatum L. [Rus. krovavnik, ivanova krov', semibratniaia krov', Ukr. krivtsa, bozha krivtsa, Khristova krivtsa, Bel. siamionava krow, kryvawnik, Cz. krevniček, krvavnik], all relate to the leaves which, in some species, have red spots, as well as to the sap which is red, as are the petals when they are crushed. In Serbian tradition, the red spots on the leaves are explained as Our Lady's blood, which dripped onto the leaves of this plant when she was menstruating - hence its name of bogorodichina trava, or bogoroditsa, bogorodichitsa, gospino tsveche, gospina tarva, gospino zelie [the herb of the Theotokos] [Čajkanović 1985: 259].

In Serbia peonies are believed to take their color from blood shed at the battle of Kosovo Field in 1389, while in Dobrich in northeastern Bulgaria the different colors of peonies are explained thus: the black ones grew out of the blood of gypsies, the blue from the blood of Turks, and the red from the blood of the Serbs [Radenković 1996: 36-37].

Another plant, Lady's thumb or Redshank, Polygonum persicaria L. also has dark red spots on its leaves. It is believed that the leaves were used by the Blessed Virgin when she was menstruating, which is why in one local Serbian tradition the plant is known as trava majke božje [the herb of the Mother of God]. The herb can also be called golgotska trava or hristova krv [Calvary herb, Christ's blood] because it allegedly grew on Calvary, where the blood of the crucified Christ blood dripped onto it, resulting in its spotted leaves [Shpis-Ćulum 1995: 425 (29)].

In one Serbian song Pavle's young wife, who is jealous of his sister and her closeness to her husband, kills his steed, his falcon, and her own 
child in that order, and then blames her sister-in-law. Pavle then kills his sister, whereupon sweet-smelling flowers - immortelle and basil - grow out of her blood. By contrast, the blood of the wicked wife gives birth to nettles and thorns [Sofrić 1990: 202].

\section{The Human Body in General}

The etiological legend about a brother and a sister turned into a flower because of their incestuous relations is well known among the East Slavs. This motif served as the basis for plant names like the Russian bratki [brothers], brat-sestra [brother-sister], ivan-da-mar'ia [Ivan and Maria] which refer usually to two kinds of flowers: the blue cow-wheat, Melampyrum nemorosum L., and the violet, Viola tricolor L., which possesses the unusual feature of combining two colors in one flower [Chubinskii 1872: (I, 1), 82; PA: XXI 10 e.]. There are also texts where there is no connection with incest: in a Belarusian variant from the Homel' region a father abandons his son and daughter in the forest. Grief then makes them turn into the flower bratki [Usacheva 2000: 282].

In a Croatian song wormwood grows from the body of a woman who slandered her daughter-in-law whom the earth would not accept [Usacheva 2000: 273]. Elsewhere it is believed that tobacco grew from the dust of the devil's corpse or from the body of the woman who cut off the head of John the Baptist [Bulashev 1909: 380, 38]. The putrid smell of elder, according to Ukrainian and Polish legend, came about because this was the tree on which Judas hanged himself [SA 1:268].

Chicory often grows on roadsides as though it was awaiting someone, leading to it being named in Czech čekanka, from čekat 'to wait'. The name is connected with a legend about a girl named Chekanka, who killed herself on her sweetheart's grave and turned into a chicory plant; Cichorium sativum, which then received her name [Sofrić 1990: 41].

Belief that an individual may have a double in the natural world is widespread, with the associated idea that you must never harm these natural doubles for fear of harming the person himself. In Leskovats (Serbia) people believed that certain trees act as an individual's double and hence, as soon as the tree falls, the person will immediately die. In Montenegro, when twins plant fruit trees at the same time, the one whose tree is the first to wither will be the first to die. For the Hutsuls an uprooted apple-tree was an omen of the death of the master or mistress of the house. And conversely, in Poles'e after the death of the master or 
mistress an apple or pear-tree would be felled. Pregnant women were not allowed to participate in the grafting of fruit trees, as it was believed that the baby would die if the graft failed to take or the tree was felled [Agapkina 1994: 85, 87].

The custom of planting a tree after a child is born is widely known. Usually it was a fruit tree or a tree with positive symbolic associations such as an oak or a birch. If one of these trees died, it was believed, the person to whom it belonged would also shortly die. Aspen, a tree with negative connotations was seldom used as a human double, and then only in an inverted relationship, such as in the Russian rite of planting a young aspen near the house when a child was ill: if the tree died, the child was supposed to survive, and vice versa [SA 3: 570].

In some rituals plants were used as a complete substitute for the individual, especially in communication with the other world. For example, in Western Serbia, in the rite of "ransoming" a twin brother or jednomesechić [a person born in the same month], the brother who was doing the redeeming would place a large white or yellow flower on the dead brother's chest, saying: "Ја теби бели цвет, - ти мени бели свет!" [I [give to] you a white flower, - you [give me] the great wide world!] [Tolstoi 1988: 86-87]. (5) Finally, in northwestern Bulgaria, in the Montana district, there existed a death-wedding rite for young people who died before they could marry. In this rite a dead youth was "married" to a stone with a woman's headscarf tied round it, and a dead maiden to a bramble branch [Vinogradova 2000: 325].

\section{Male/female}

It was widely believed that a tree could have a "gender", as, for example, in the folk images of the birch as a female symbol, and the oak and the sycamore as male. Among the East Slavs planting a fir or a birch near a house was banned because they would "drive the women out" of the house, while it was a Serbian custom to take the chemise of a woman who had recently been confined and place it under a male or female tree, depending on whether she wanted her next child to be a boy or a girl [SA 2: 62]. Furthermore, trees of different "sexes" were thought capable of having relationships with each other and of passing these capacities on to humans, as can be seen from the use in love magic of bark taken from a site where a "male" and a "female" tree (a birch and an oak, for example) grew together [SA 2: 63]. Finally, Bulgarians in the Pirin region in southwest Bulgaria believed that the ash and mulberry are brother and 
sister, and so would never rub twigs from these two trees together when making a fire.

\section{Barrenness and Children}

The arrival of children in this world was very often connected with plants (especially in euphemistic explanations about their genesis).(6) Children were told that they had been found among the cabbages, potatoes, cucumbers, onions or pumpkins, or else in flowers, nettle, thistle, on a pussy-willow, birch, oak, pine, apple-tree etc. [Vinogradova 2000: 353-54]. The floral code is also dominant in expressions denoting an illegitimate child; typical of this are kapustnichek and krapivnik in Russian, koprivník in Czech and Polish pokrzywnik, all meaning a cabbage or nettle child [Machek 1971: 275].

A woman who was menstruating was able to pass her ability to "blossom" on to a tree, if it was not bearing any fruit. Conversely, it was thought that a woman who was barren would deprive a tree of its fertility by her touch or glance. To escape her infertility she had to eat particular parts of a fruit tree; for example, the three first buds or flowers, the first fruits (though this was detrimental to the tree) or the fruit of the second harvest in the same year. Another way of escaping infertility was to hang your shirt on a fruit tree upside down for a night and then the next morning to eat any living creature (such as an ant or a beetle), that had become trapped in it [SA 1: 167; Agapkina 1994: 85-86]. Even today the belief that giving birth to twins is the result of eating double fruits, for example apples that have grown together, persists in a number of areas.

All these data demonstrate the close mutual influence between the human and plant worlds. They may exchange fertility, but the process should be balanced. The excessive accumulation of vital energies on one side destroys the natural balance, and the situation can only be corrected at the expense of victims from the other side. An example is the belief, familiar to all the Slavs, that if fruit trees blossom twice in the same year then this is a sign of an impending disaster (high mortality or famine in the village, death or a bastard in the family) [Nikiforovskii 1897: 127 nos 925, 926; Demich 1899: 1262]. Here an excessive concentration of vital energies in one part of the whole formed by nature and culture must be compensated at the expense of the other.

\section{Disease}

Passing on an illness is a common form of healing among the Slavs, and a disease could be passed to a person, to cattle, or to an object, as 
well as to plants; thus the Belarusians "passed on" a fever to the aspen, while the East Slavs as a whole promised the mountain ash that they would not break its branches nor eat its berries in exchange for its curing their toothache. A tree might also be threatened and such threats would be accompanied by bending the top of a tree to the ground.

Mouse bloodwort, Hieracium pilosella L., is known in Ukrainian as nechui viter [the not-feeling-the-wind herb], as the leaves of this lowgrowing plant do not move in the wind. This explains its use as a treatment for fever [Annenkov 1876: 167] - the essential quality of not feeling or not reacting found in the plant is to be passed to the sick person.

\section{Character}

Plant names can also be used for delineating character; thus, in wedding songs, the new relatives of a young married woman (her mother-in-law or sisters-in-law) are often compared with stinging nettles or the thorny dog-rose. In a Ukrainian folk tale from the Kharkiv region the children, whose father was a grass snake, turned into plants after their father's death. The treacherous daughter, who had betrayed the secret of her father's identity, became a nettle after her mother uttered a curse over her: "И будешь ты всегда причинять людям жгучую боль, как теперь ты причинила ее мне!" [For ever shall you cause others fiery pain, just as you did to me!]. By contrast her brother Vasia, who had kept the secret, turned into sweet basil (Ukr. vasil'ki). Before this happened, his mother said to him: "Люди будут наслаждаться твоим запахом и будут всегда держать тебя в своих хатах и в своих церквах!” [People will enjoy your scent and keep you always in their houses and churches!] [P. I. 1891: 125-28].

\section{Emotions and States}

\section{Grief}

The appearance of a given flower may evoke an association with a particular emotion. Thus the water (or purple) avens, Geum rivale L., acquired the name of paniknitsa [the limp herb] in Belarusian dialect because of its drooping flowers [Gancharyk 1927: 194]. An association of this kind may serve as a basis for a plant's use, as in Perm' province where the nodding catchfly, Silene nutans L., is known as potoskuika [the wistful herb], because its flower heads bent down to the ground as 
though in grief. As a result, this plant was thought to be able to cure grief, sadness, and similar afflictions [Krylov 1876: 81].

Fear

Some texts explain not the origin of the plant itself, but its distinctive feature, for example the trembling of the aspen. In one Bulgarian legend a serpent marries a girl and they have a daughter called Treperushka, who betrays her father's secret to her relatives on her mother's side. They then kill him. On his deathbed he changes his daughter into a tree, which will shake day and night, and curses her: “ТТзе, Треперико, дрво да станеш и ден' и ношк'а мирка да немаш, зиме и лете се да трепереш!" [Treperika, become a tree, know no rest day and night, and shake in winter and in summer!] [SA 3: 570]. Similarly, it was believed that the trunk of the birch turned white with fear, when Judas wanted to hang himself on it.

\section{Shame}

Bur-parsley, Caucalis grandiflora, is known in Serbian as stidak, sramak, meaning shame. The flower is white with a red spot in the middle, and the Serbs explain the name by saying that in days of yore the flower had more red on it, but nowadays it has less and less because shame in people is disappearing [Čajkanović 1985: 223; Sofrić 1990: 207].

\section{Sleep}

The meadow pasqueflower, Pulsatilla pratensis and Pulsatilla latifolia, are known in Russian as son-trava, and Belarusian as son lugavy, son-trava [the sleeping herb] because of the limp form of the plant, whose flower almost touches the ground.

\section{Conclusion}

It has been possible to see the dependence of the symbolic aspects of a plant on its features, with several semantic models for likening a plant and a body part: color, form, smell, the ability to sting and so on. These features are reflected in phytonyms, phraseology, folklore (above all in etiological legends), and, lastly, in the way plants are used in folk magic and medicine.(7) The three levels of language, folklore and ritual are connected, though it is not always possible to find all three for one specific motif. The most important feature here, it may be assumed, is the shape of a plant - that is, the similarity in form with a human body 
part. When a phytonym is based on its usage, the deeper reason is form again (as, for example, in healing headaches). Size becomes important in actions involving plants only in the case of vegetables.

The anthropomorphization revealed in the data discussed in this article works as a structuring force, regulating folk knowledge about the world of plants. However, what we find is not just mutual relations between two codes, but a complex system, where sustainability is maintained in at least two ways. The system works "vertically" in the possibility of expressing the same meaning using a word - the name of a plant - or a folklore text and in the use of plant symbolism in the enactment of ritual. The system also works "horizontally" in the possibility of expressing the same meaning through different codes. For example, the motif of the "grass-snake's wife" seen in the floral code (here floral includes both trees and herbs) also exists in teriomorphic code: the daughter turns into a frog, or the son into a nightingale [SA 3: 39]. Such an example demonstrates the systematic character of the mythological model of the world.

\section{NOTES}

1 This article was first published in a slightly altered form in Slovene in Človeško telo in "Rastline. Medsebojni odnosi med dvema sistemoma poimenovanja", Etnolog. Glasnik Slovenskega etnografskega muzeja, 2005, 15: 137-50.

2 This may refer to Eryngium planum L.

3 This may refer to Anastatica hierochuntica L.

4 The orchid family, orchidaceae, has tuber-like roots, with the strong new root adjoining the previous year's dying root.

5 Such people were supposedly so closely connected that the death of one led inevitably to the death of the other. To prevent the second death, the rite of "ransoming" was necessary.

6 Children may also be "brought" by animals and birds (a hare, stork, raven, goose, hawk, swan, cuckoo or sea-gull), or by other humans (an old woman, gypsies or travelers sent by God). They can also be "purchased" [Vinogradova 2000: 349].

7 In manuscript herbals, the form and color of plant roots also played a main role in love magic. The features and functions of the herbs can therefore be used to help identify the plants described in early herbals. 


\section{BIBLIOGRAPHY}

Afanas'ev, Aleksandr. 1994 [1865-69]. Афанасьев, Александр. Поэтические воззрения славян на природу: В 3-x $\mathrm{m}$. [The Slavs' Poetic Conception of Nature. 3 vols.]. Reprinted from the edition of 1865-1869. Vol. 3. Москва: Индрик.

Agapkina, Tat'iana. 1994. Агапкина, Татьяна. “Южнославянские поверья и обряды, связанные с плодовыми деревьями, в общеславянской перспективе" [Southern Slavonic Beliefs and Rites, Connected with Fruit Trees, from a General Slavonic Perspective] в Славянский и балканский фольклор. Верования. Текст. Ритуал. Ред. Никита Толстой. [Slavonic and Balkan Folklore. Faith. Text. Ritual. Nikita Tolstoi, ed.] Москва: Индрик. 84-110.

Annenkov, Nikolai. 1876. Анненков, Николай. Ботанический словарь [Botanical Dictionary]. Санкт-Петербург: Тип. Имп. Академии Наук.

Avgustinovich, F. М. 1853. Августинович, Ф. М. “О дикорастущих врачебных растениях Полтавской губернии" [On the Medicinal Wild Plants of Poltava Province], Труды комиссии высочайше учрежденной, при императорском ун-те св. Владимира для описания губерний Киевского учебного округа. Vol. 2. Киев: В Университетской типографии, 1-91.

Bulashev, G. O. 1909. Булашев, Г. О. Украинский народ в своих легендах и религиозных воззрениях и верованиях Вып. 1 Космогонические украинские народные воззрения и верования [The Ukrainian People in their Legends, Religious Views and Beliefs. Issue 1. Ukrainian Folk Ideas and Beliefs about the Creation of the World]. Киев: Типогр. Имп. Ун-та св. Владимира Акц. Об-ва Н. Т. Корчак-Новицкого.

Čajkanović, Veselin. 1985. Чајкановић, Веселин. Речник српских народних верована о биљкама [Dictionary of Serbian Popular Beliefs about Plants]. Београд: Српска књижевна задруга.

Chubinskii, Pavel. 1877. Чубинский, Павел. Tруды этнографическостатистической экспедиции в западно-русский край [Publications of the Ethnographic-Statistical Expedition to the West of Russian]. Vol. I. Issue 1. 1872; Vol. I. Issue 2. СанктПетербург: В. Безобразов.

Demich, V. F. 1899. Демич, В. Ф. “Легенды и поверья в русской народной медицине" [Legends and Beliefs in Russian Folk 
Medicine], Вестник общественной гигиены, судебной $и$ практической медицины 9 (September): 1151-1181; 10 (October): 1240-1267.

Dobrovol'skii, Vladimir. 1914. Добровольский, Владимир. Смоленский областной словарь [Dictionary of the Smolensk Region]. Смоленск: Тип. П. А. Силина.

Gancharyk, M. M. 1927. Ганчарык, М. М. "Беларускія назовы расьлін". Ч. 1 [Belarusian Plant Names. Part 1], Праца Навуковога таварыства па вывучэнню Беларусі II. Горы-Горкі: Друкарня і камнядрук Акадэміi, 194-216.

Ivanitskii, N. А. 1890. Иваницкий, Н. А. "Материалы по этнографии Вологодской губ." [Materials on the ethnography of Vologda province], Известия общества любителей естествознания, антропологии и этнографии. Vol. 69. Труды этнографического отдела. Vol. 11. Issue 1: 1-231.

Kedrina, R. Е. 1912. Кедрина, Р. Е. “Обряд крещения и похорон кукушки в связи с народным кумовством" [The Baptism and Burial Rite of the Cuckoo and its Connection with Folk kumovstvo], Этнографическое обозрение 1-2: 101-139.

Kharitonov, A. 1848. Харитонов, А. "Врачевание, забавы и поверья крестьян Архангельской губернии, уездов: Шенкурского и Архангельского" [Healing, Pastimes and Beliefs of the Peasants of Archangel Province, Shenkursk and Maloarchangelsk uezd], Отечественные записки: 5-6, vol. 58. Miscellaneous section: 124.

Khatemkin, A. G. 1900. Хатемкин, А. Г. "Приворотные средства" [Love Potions], Киевская старина 68 (4), April: 8-9.

Krylov, P. 1876. Крылов, П. “О народных лекарственных растениях, употребляемых в Пермской губернии" [On Folk Medical Plants used in Perm' Province], Tруды общества естествоиспытателей при Императорском Казанском Университете 5 (Issue 2). Казань: Тип. Императорского Университета.

Krylov, P. 1882. Крылов, П. “Некоторые сведения о народных лекарственных средствах, употребляемых в Казанской губернии" [Some Information about Folk Remedies, used in Kazan' Province], Труды общества естествоиспытателей при Императорском Казанском Университете 11 (Issue 4). Казань: Тип. Императорского Университета. 
Machek, Vaclav. 1954. Česká a slovenská iména rostlin [Czech and Slovak Plant Names]. Praha: Nakladatelství Československé Akademie Věd.

Machek, Vaclav. 1971. Etymologický slovnik jazyka českého [Etymological Dictionary of the Czech Language]. Praha.

Markevich, N. 1860. Маркевич, Н. Обычаи, поверья, кухня и напитки малороссиян [Customs, Beliefs, Cuisine, and Drinks of the Ukrainians]. Киев: В типографии И. и А. Давиденко.

Markovich, V. V. 1891. Маркович, В. В. Знахарки нового типа [A New Type of Magic Healer], Киевская старина 35 (December): 413-429.

Moroz, Andrei. 2000. Мороз, Андрей. "Народное огородничество у восточных славян как система кодов" [Eastern Slavs' Folk Gardening as a System of Codes], Кодови словенских култура 5: 131-145.

Nikiforovskii, N. Іа 1897. Никифоровский, Н. Я. Простонародные приметы и поверья, суеверные обряды и обычаи, легендарные сказания о лицах и местах [Folk Omens and Beliefs, Superstitious Rites and Customs, Legends about Persons and Places]. Витебск: Губ. типо-лит.

PA. Полесский архив [Poles'e Archive], Институт Славяноведения РАН, Москва).

P. I[vanov]. 1891. П. И[ванов]. “Из области малорусских народных легенд" [On Ukrainian Folk Legends], Этнографическое обозрение 2: 110-132.

Potanin, G. 1899. Потанин, Г. “Этнографические заметки на пути от г. Никольска до г. Тотьмы" [Ethnographic Jottings on the Road from Nikol'sk to Tot'ma], Живая старина 1: 23-60; 2: 167-239.

Radenković, Ljubinko. 1996. Раденковић, Љубинко. Симболика света y народној магији јужних словена [The Symbolism of the World in the Folk Magic of the South Slavs]. Ниш: Просвета.

Rodionova, Inna. 2002. Родионова, Инна. "Библейские мотивы в народных названиях растений" [Biblical Motifs in the Folk Names for Plants], Живая старина 2: 38-39.

SA - Славянские древности: Этнолингвистический словарь в 5 т. [Slavic Antiquities: Ethnolinguistic Dictionary in 5 vols.]. 1995. Vol. 1.; 1999. Vol. 2.; 2004. Vol. 3. Москва: Международные отношения.

Shpis-Ćulum, Marija. 1995. Шпис-Ћулум, Марија. “Фитонимија југозападне Бачке (коровска флора)" [The Phytonyms of South- 
West Bachka (Weeds)], Српски дијалектолошки зборник 41: 397490.

Sikimić, Biljana. 1996. Сикимић, Биљана. “Еротске конотације фитонима у народним загонеткама" [The Erotic Connotations of Phytonyms in Folk Riddles], Кодови словенских култура 1: 57-67. Sofrić, Pavle. 1990. Софрић, П. Главније биље у народном вероваюу и предағу код нас Срба [The Main Plants in Folk Belief and Legend among the Serbs]. Београд: БИГЗ.

Tolstoi, Nikita. 1988. Толстой, Никита. “Заклинания, связанные с институтом побратимов и «одномесячников»" [Charms, Connected with the Institution of Adopted Brothers and "MonthMates"], в Этнолингвистика текста. Семиотика малых форм фольклора I. Тезисы и предварительные материаль $\kappa$ симпозиуму. Ред. Вячеслав Иванов. [Ethnolinguistics of a Text. Semiotics of Small Folklore Forms I. Theses and Preliminary Materials for the Symposium. Viacheslav Ivanov, ed.] Москва: Инт славяноведения и балканистики. 85-88.

Usacheva, Valeriia. 2000. Усачева, Валерия. "Мифологические представления славян о происхождении растений” [The Slavs' Mythological Conceptions about the Genesis of Plants], в Славянский и балканский фольклор. Народная демонология. Ред. Светлана Толстая. [Slavonic and Balkan Folklore. Folk Demonology. Svetlana Tolstaia, ed.] Москва: Индрик. 259-302.

Vinogradova, Ludmila. 2000. Виноградова, Людмила. Народная демонология и мифо-ритуальная традиция славян [Folk Demonology and the Mytho-Ritual Tradition of the Slavs]. Москва: Индрик.

Zalesova, E. N. and O. V. Petrovskaia. 1898-1901. Залесова, Е. Н. и О. В. Петровская. Полный иллюстрированный словарь-травник $и$ цветник, составленный по новейшим ботаническим и медицинским сочинениям врач. $E$.H. Залесовой и О. В. Петровской: В $4 \mathrm{~m}$. [Complete Illustrated Dictionary - Herbal Book, Collected from the Newest Botanic and Medical Works by Drs E. N. Zalesova and O. V. Petrovskaia]. Санкт-Петербург: A. A. Каспари. 